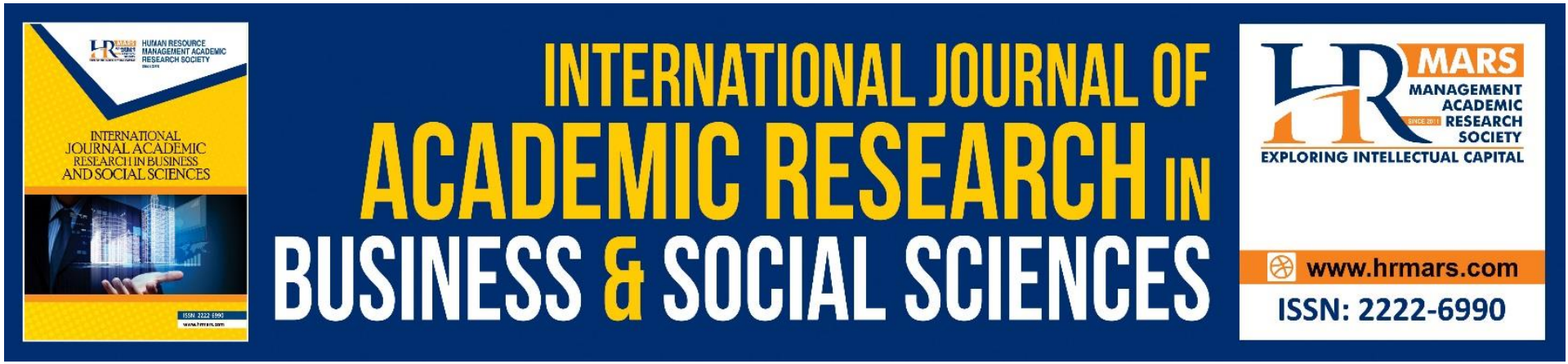

\title{
External Debts and Economic Growth in Malaysia
}

\section{Siti Fazilah Alwi, Hock-Ann Lee, Nur Shahirah Azman, Huay-Huay Lee}

To Link this Article: http://dx.doi.org/10.6007/IJARBSS/v10-i12/8373

DOI:10.6007/IJARBSS/v10-i12/8373

Received: 30 October 2020, Revised: 27 November 2020, Accepted: 19 December 2020

Published Online: 24 December 2020

In-Text Citation: (Alwi et al., 2020)

To Cite this Article: Alwi, S. F., Lee, H.-A., Azman, N. S., \& Lee, H.-H. (2020). External Debts and Economic Growth in Malaysia. International Journal of Academic Research in Business and Social Sciences, 10(12), 755-768.

Copyright: (c) 2020 The Author(s)

Published by Human Resource Management Academic Research Society (www.hrmars.com) This article is published under the Creative Commons Attribution (CC BY 4.0) license. Anyone may reproduce, distribute, translate and create derivative works of this article (for both commercial and non-commercial purposes), subject to full attribution to the original publication and authors. The full terms of this license may be seen at: http://creativecommons.org/licences/by/4.0/legalcode

Vol. 10, No. 12, 2020, Pg. 755 - 768

Full Terms \& Conditions of access and use can be found at http://hrmars.com/index.php/pages/detail/publication-ethics 


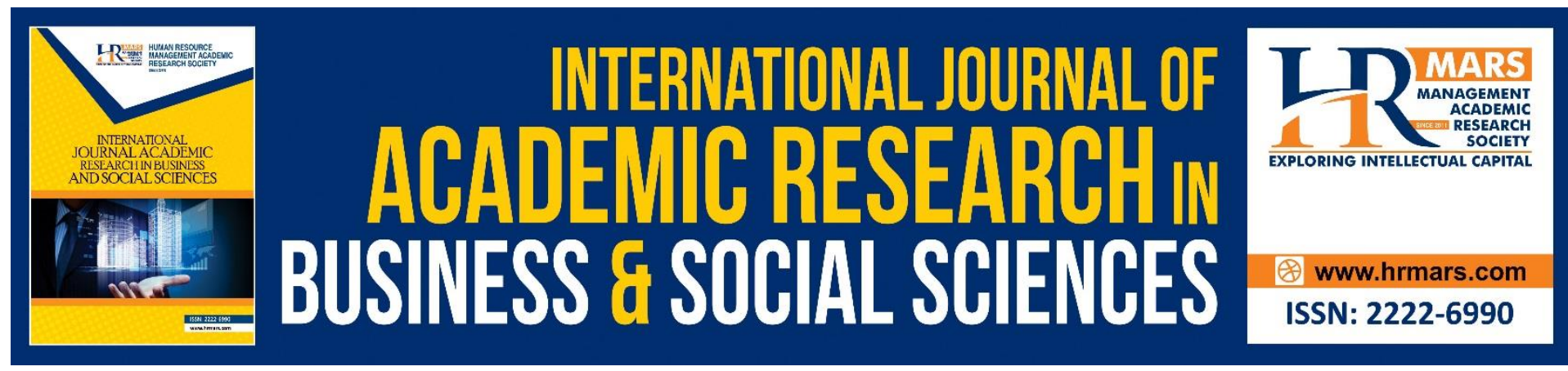

\title{
External Debts and Economic Growth in Malaysia
}

\section{Siti Fazilah Alwi ${ }^{1}$, Hock-Ann Lee ${ }^{1}$, Nur Shahirah Azman ${ }^{1}$, Huay- Huay Lee ${ }^{2}$}

${ }^{1}$ Labuan Faculty of International Finance, Universiti Malaysia Sabah, Jalan Sungai Pagar, 87000 W.P. Labuan, Malaysia, ${ }^{2}$ Faculty of Business, Multimedia University, Jalan Ayer Keroh Lama 75450, Bukit Beruang, Melaka, Malaysia

Email: hockann@ums.edu.my

\begin{abstract}
Previous researches on the relationship between external debt and economic growth in Malaysia have produced inconsistent results. Despite the intense debate on the link between external debt and economic growth, there is no research that takes the new definition of external debt into consideration. To address this issue, this study seeks to examine the effects of external debt on economic growth by allowing the external debt to be taken into consideration especially in terms of the non-residents holding of local-currency denominated debt securities. Using time series econometric approaches and quarterly data of Malaysia from 1997 Q1 to 2016 Q4, this study finds that there is a significant positive relationship between external debt and economic growth. In addition, the results of Granger causality test reveal the existence of short-run bilateral causality relationships between external debt and economic growth.
\end{abstract}

Keywords: External debt, Economic Growth, Foreign Holding of Local-Currency Debt, Malaysia

\section{Introduction}

In 2014, Malaysia's external debt was redefined to be consistent with International Monetary Fund (IMF) practices, causing a sharp increase in external debt. After the implementation of the new definition of external debt, Malaysia's external debt rose to RM908.7 billion (or 73.9\% of GDP), compared to the previous definition, which was recorded at RM524.3 billion (or 42.7\% of GDP) at the end of 2016 (Bank Negara Malaysia, 2016). Figure 1 shows that GDP growth has dropped since 2010, while Malaysia's external debt has increased over the years, especially after the Central Bank of Malaysia adopted the new measurement of external debt. Moreover, Moody's Investors Services Report also indicates that the country's external debt to GDP ratio is higher than other large economies in the Asia Pacific region, which stood at 66\% of GDP in 2015 (Roscoe and Duggar, 2016).

As Malaysia slowly recovers from its financial crisis, the economic environment remains challenging throughout the years. The Government needs large capital to enhance the country's economic growth. Hence, external funds have become one of the funding alternatives for the government when domestic funds are insufficient to finance expenditure (Daud et al., 2013). However, external debt rescheduling and the insufficient use of these 
resources might lead to a higher level of external debt and rise debt servicing, causing detrimental economic growth. Therefore, the dramatic increase in external debt led to an intense debate on whether it could help to improve economic performance, or become a burden to the country.

Figure 1: Malaysia's External Debt and GDP Growth

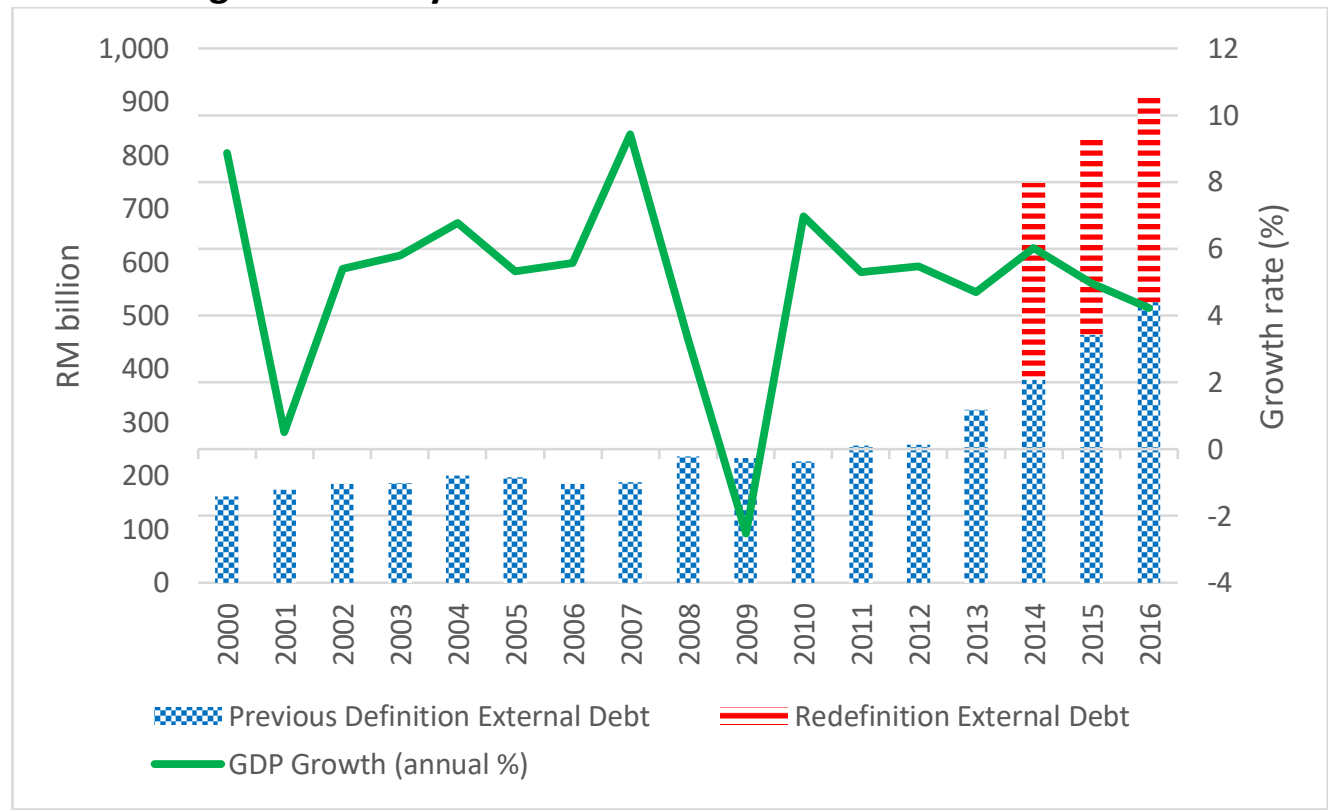

Source: Central Bank of Malaysia

\section{Non-resident Holdings of Domestic Debt Securities}

According to the Central Bank of Malaysia, the redefinition of external debt includes nonresident domestic debt securities, trade credits, currency and deposits, as well as other loans and liabilities. In contrast, non-resident holdings of domestic debt securities contribute to about two-thirds of the increase in redefined external debt (Bank Negara Malaysia, 2014).

Figure 2: Non-Resident Holdings of Regional Countries Government Bonds

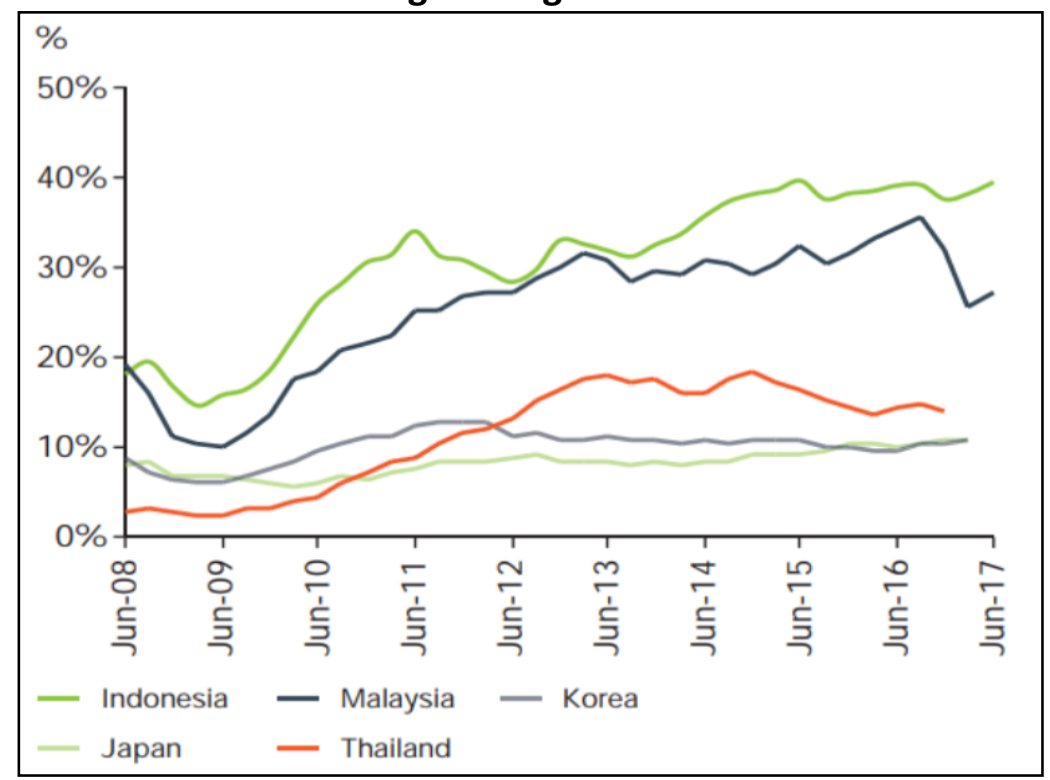

Source. Asian Bonds Online 
Figure 3: Malaysia External Debt Composition (Quarterly)

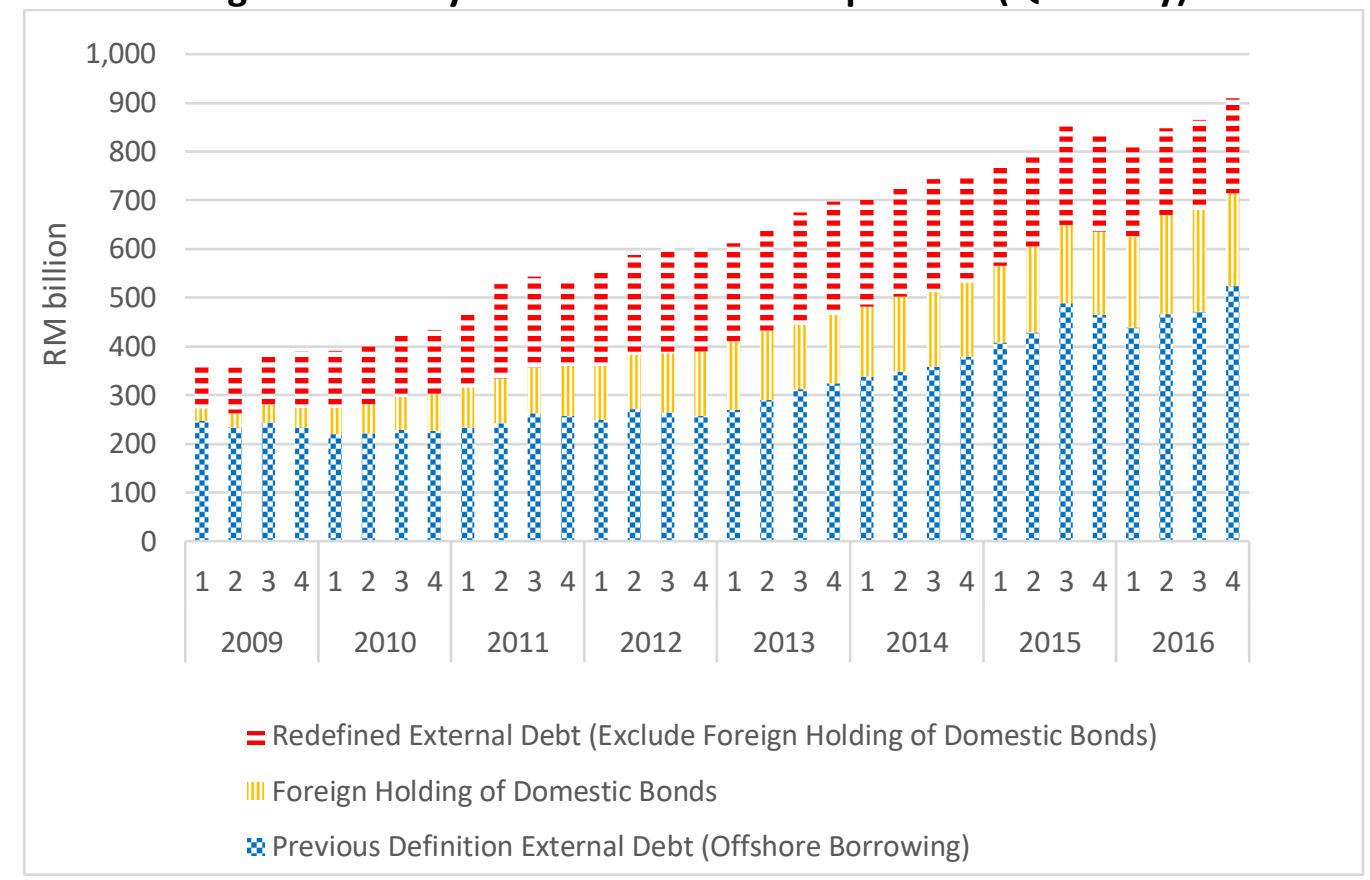

Source: Central Bank of Malaysia

Non-resident investors are interested to invest in the Malaysian bond market due to its liquid and investor-friendly market. Figure 2 indicates that Malaysia has among the highest non-resident investors participation in the region, after Indonesia. Despite the reduction of non-resident holdings of Malaysia Government Securities (MGS) in November, 2016, Malaysia is still higher compared to Thailand, Japan and Korea. Figure 3 shows that non-resident holdings of domestic bonds contribute to almost half of the redefined external debt. Additionally, Abdullah and Razali (2017) report that non-resident holdings of medium- and long-term Malaysian government bonds are more than $65.0 \%$. They also explain that foreign investors' demand for the Malaysian bond market has brought significant benefits by enhanced liquidity, and additional demand has also helped to reduce government borrowing costs when raising funds from the bond market.

However, the high demand of non-resident holdings of domestic bonds also brings with it challenges, where non-resident holdings of domestic bonds contribute to a high level of external debt. The IMF also indicates that Malaysia suffers uncertainty external risks due to significant capital outflows where foreign investors still hold fairly large positions in MGS; and Malaysia remains exposed to further outflow (International Monetary Fund, 2016). The sudden capital outflows may create volatility in the domestic financial markets. Therefore, this study attempts to address this gap in the related body of literature by taking the redefinition of external debt into account. However, this study only includes the long-term non-resident holdings of domestic debt securities into the old definition of external debt, due to data unavailability.

This paper is organised as follows. Section 2 reviews the literature on the theories related to linkage between external debt and economic growth. Section 3 explains the methodology and data collection procedures, while Section 4 presents the results. Section 5 concludes. 


\section{Literature Review}

The debt overhang theory implies that a high level of external debt reduces economic growth through crowding out investments, although the theory does not explicitly consider economic growth (Krugman, 1988). The literature that investigates the link between external debt and economic performance was initiated by Griffin and Enos (1970), who claim that there exists a negative effect of foreign assistance on economic growth. Later, a growing number of empirical studies have found a negative relationship between external debt and economic growth. Using panel data for 35 Sub-Saharan African countries, Fosu (1999) demonstrated a significant negative link between external debt and economic growth. Elbadawi, Ndulu, and Ndung'u (1997) conducted one of the earlier studies that directly consider the nonlinear effects of external debt on economic growth, using fixed and random effect panel estimation for 99 developing countries including sub-Saharan Africa. The authors found that debt to GDP ratio affects growth positively up to the peak of 97 percent. Were (2001) investigated time series data for the period of 1970-1995 and revealed that the accumulation of external debt appears to discourage Kenya's economic growth. Furthermore, Pattillo, Poirson, and Ricci, (2002) as well as Clements, Bhattacharya, and Nguyen (2003), employed a large country sample and found that a high level of external debt accumulation has a negative impact on overall economic growth. By investigating the role of external debt on economic growth, Schclarek (2004) as well as Schclarek and Ramon-Ballester (2005), found a negative effect of public external debt on economic growth rather than private external debt. Reinhart and Rogoff (2010), after examining a cross section sample of 44 countries covering about two hundred years, confirmed a strong negative link between debt and economic growth, particularly when debt rises above $60 \%$ of GDP. Using an unbalanced panel of 79 developing countries over the period 1970-2002, Cordella, Ricci, and Ruiz-Arranz (2010) found that external debt hinders economic performance when debt is at an intermediate level, while at very high and very low levels of debt, they did not find any significant relationship. Covering the period of 1976-2011, Shabbir (2013) indicate that there exists a negative effect of external debt on economic growth by using a panel sample of 70 developing countries, including Malaysia. By studying Malaysia, Thailand and the Philippines over 50 years, Lau, Lee, and Baharumshah (2015) found a significant long-run relationship between external debt and economic productivity.

However, several empirical studies have shown a positive effect of external debt on economic growth. By examining panel data for six Pacific Island Countries (PIC) over the 19882004 period, Jayaraman and Lau (2009) reveal positive linkage between external debt and economic performance. Abdelhadi (2013) show that the relationship between foreign debt and Jordan's economic growth is positive. In their time series analysis, Jilenga, Xu, and Gondje-Dacka (2016) examine Tanzania for the sample period of 1971-2011, and found a positive long-run correlation between external debt and economic growth. Ahmed, Butt, and Alam (2000) indicate no evidence of a joint feedback affect between export revenue, foreign debt service and economic growth by using a time series sample of eight selected Asian countries, including Malaysia, for the period 1970-1977.

Foreign debt has become among the important sources of domestic capital to finance a country's economic development, especially for a small open economy country such as Malaysia. Therefore, some studies focus on the relationship between external debt and economic growth, in the context of Malaysia. By using Vector Autoregression (VAR) estimation for the period of 1970-2005, Bakar and Hassan (2008) indicate that external debt in Malaysia affects economic growth positively at the aggregate level. Their empirical results 
indicate that after a $1 \%$ rise in total external debt, the economic growth will increase by 1.29\%. On the other hand, using Autoregressive Distributed Lag (ARDL) estimation for the period of 1991-2009, Daud, Ahmad, and Azman-Saini (2013) suggest a significant positive relationship between external debt and economic growth in the country. However, by examining the existence of a threshold effect, they claim that the accumulation of external debt increases economic growth up to a maximum threshold level, and the continuous increase of external debt beyond this level will hurt Malaysia's economic growth. In contrast, Choong, Lau, Liew, and Puah (2010) investigate the impact of various types of debt (including external debt) on economic growth for the period of 1970-2006. Their results imply that all debt types have long-run negative effects on economic growth. In the short-run, they also found that economic growth using Granger causes external debt.

Previous studies provide mixed results on the relationship between external debt and economic growth. Therefore, this study investigates whether external debt helps to boost or hinder economic growth in Malaysia, over the period of 1997 Q1 to 2016 Q4.

\section{Methodology}

\section{Model Specification}

In this study, the growth model to be estimated is defined as follows:

$$
\begin{aligned}
& G D P_{t}=\beta_{0}+\beta_{1} D E B T_{t}^{O L D}+\beta_{2} G R E V_{t}+\beta_{3} I N V S_{t}+\beta_{4} I N F_{t}+\varepsilon_{t} \\
& G D P_{t}=\beta_{0}+\beta_{1} D E B T^{N E W_{t}}+\beta_{2} G R E V_{t}+\beta_{3} I N V S_{t}+\beta_{4} I N F_{t}+\varepsilon_{t}
\end{aligned}
$$

where $\beta_{0}$ is a constant, GDP is the real gross domestic product, DEBT ${ }^{\mathrm{OLD}}$ is the previous definition external debt as a ratio of GDP, DEBT ${ }^{\mathrm{NEW}}$ is the redefinition external debt as a ratio of GDP, GREV is government revenues as a ratio of GDP, INVS is the gross fixed capital formation (investment) as a ratio of GDP, INF is inflation (measured based on Consumer Price Index) and $\varepsilon$ is an error term. The sample period considered in this study covers the period of 1997 Q1 to 2016 Q4. All data were collected from the Central Bank of Malaysia, Monthly Statistical Bulletin.

\section{Cointegration}

An Autoregressive Distributed Lag (ARDL) bound test, developed by Pesaran, Shin, and Smith, (2001), was employed in this study to examine the existence of the long-run relationship. The ARDL approach allows various orders of integration for the variables to be determined in the long-run cointegration relationship. Under this approach, the variables that can be integrated are of $I(0), I(1)$ or mixed order of integration. The ADRL model used in this study is expressed as follows:

$$
\begin{aligned}
\Delta \ln G D P_{t}=y_{0} & +\theta_{1} \ln D E B T^{O L D}{ }_{t-1}+\theta_{2} \ln G R E V_{t-1}+\theta_{3} \operatorname{lnINVS}_{t-1}+\theta_{4} I N F_{t-1} \\
& +\sum_{i=1}^{P} \beta_{1 i} \Delta \ln D E B T_{t-1}^{O L D}+\sum_{i=1}^{r} \beta_{2 i} \Delta \ln G R E V_{t-1}+\sum_{i=1}^{S} \beta_{3 i} \Delta \ln I N V S_{t-1} \\
& +\sum_{i=1}^{S} \beta_{4 i} \Delta I N F_{t-1}+\varepsilon_{t}
\end{aligned}
$$




$$
\begin{aligned}
\Delta \operatorname{lnGDP} P_{t}=y_{0} & +\theta_{1} \ln D E B T_{t-1}^{N E W}+\theta_{2} \operatorname{lnGREV}_{t-1}+\theta_{3} \operatorname{lnINVS}_{t-1}+\theta_{4} I N F_{t-1} \\
& +\sum_{i=1}^{P} \beta_{1 i} \Delta \ln D E B T^{N E W_{-1}}+\sum_{i=1}^{s} \beta_{2 i} \Delta \ln G R E V_{t-1}+\sum_{i=1}^{s} \beta_{3 i} \Delta \ln I N V S_{t-1} \\
& +\sum_{i=1}^{s} \beta_{4 i} \Delta I N F_{t-1}+\varepsilon_{t}
\end{aligned}
$$

where $y_{0}$ is a constant, InGDP is the logarithm of real gross domestic product, InDEBT the logarithm of the previous definition external debt as a ratio of GDP, InDEBT ${ }^{\mathrm{NEW}}$ is the logarithm of redefinition external debt as a ratio of GDP, InGREV is the logarithm of government revenues as a ratio of GDP, InINVS is the logarithm of gross fixed capital formation (investment) as a ratio of GDP, INF is inflation (measured based on Consumer Price Index) and $\varepsilon$ is an error termequation (3) indicates the relationship between the old definition of external debt and gross domestic product, while equation (4) indicates the relationship between the new definition of external debt and gross domestic product. In the ARDL bound test, the F-statistic value was used to examine the null hypotheses of no cointegration among the variables. The null hypotheses of no cointegration is rejected if the estimated F-statistic is higher than the upper bound critical values. If the F-statistic falls in between the critical values, the relationship among the variables is inconclusive. The null hypotheses of no cointegration cannot be rejected if the F-statistic is lower than the lower bound critical value.

\section{Granger Causality}

The bound test can only suggest if there exists a cointegration relationship among the variables, but it does not indicate the direction of causality. Therefore, this study constructs the standard Granger causality test augmented with a lagged period error-correction term when the variables are cointegrated. The estimation models are as follows:

$$
\begin{aligned}
(1-L)\left[\begin{array}{c}
\Delta \ln G D P \\
\Delta \ln D E B T^{O L D} \\
\Delta \ln G R E V \\
\Delta \ln I N V S \\
\Delta I N F
\end{array}\right] \\
=\left[\begin{array}{l}
\alpha_{1} \\
\alpha_{2} \\
\alpha_{3} \\
\alpha_{4} \\
\alpha_{5}
\end{array}\right]+\sum_{i=1}^{p}(1-L)\left[\begin{array}{lllll}
\beta 1_{1 i} & \beta 1_{2 i} & \beta 1_{3 i} & \beta 1_{4 i} & \beta 1_{5 i} \\
\beta 2_{1 i} & \beta 2_{2 i} & \beta 2_{3 i} & \beta 2_{4 i} & \beta 2_{5 i} \\
\beta 3_{1 i} & \beta 3_{2 i} & \beta 3_{3 i} & \beta 3_{4 i} & \beta 3_{5 i} \\
\beta 4_{1 i} & \beta 4_{2 i} & \beta 4_{3 i} & \beta 4_{4 i} & \beta 4_{5 i} \\
\beta 5_{1 i} & \beta 5_{2 i} & \beta 5_{3 i} & \beta 5_{4 i} & \beta 5_{5 i}
\end{array}\right]\left[\begin{array}{c}
\Delta \ln G D P_{t-i} \\
\Delta \ln E B T^{O L D}{ }_{t-i} \\
\Delta \ln G R E V_{t-i} \\
\Delta \ln I N S_{t-i} \\
\Delta I N F_{t-i}
\end{array}\right] \\
+\left[\begin{array}{l}
\theta \\
\vartheta \\
\psi \\
\omega \\
\delta
\end{array}\right]\left[\begin{array}{l}
E C T_{t-i} \\
E C T_{t-i} \\
E C T_{t-i} \\
E C T_{t-i} \\
E C T_{t-i}
\end{array}\right]+\left[\begin{array}{c}
\varepsilon_{1 t} \\
\varepsilon_{2 t} \\
\varepsilon_{3 t} \\
\varepsilon_{4 t} \\
\varepsilon_{5 t}
\end{array}\right]
\end{aligned}
$$




$$
\begin{aligned}
(1-L)\left[\begin{array}{c}
\Delta \ln G D P \\
\Delta \ln D E B T^{N E W} \\
\Delta \ln G R E V \\
\Delta \ln I N V S \\
\Delta I N F
\end{array}\right] \\
=\left[\begin{array}{c}
\alpha_{1} \\
\alpha_{2} \\
\alpha_{3} \\
\alpha_{4} \\
\alpha_{5}
\end{array}\right]+\sum_{i=1}^{p}(1-L)\left[\begin{array}{lllll}
\beta 1_{1 i} & \beta 1_{2 i} & \beta 1_{3 i} & \beta 1_{4 i} & \beta 1_{5 i} \\
\beta 2_{1 i} & \beta 2_{2 i} & \beta 2_{3 i} & \beta 2_{4 i} & \beta 2_{5 i} \\
\beta 3_{1 i} & \beta 3_{2 i} & \beta 3_{3 i} & \beta 3_{4 i} & \beta 3_{5 i} \\
\beta 4_{1 i} & \beta 4_{2 i} & \beta 4_{3 i} & \beta 4_{4 i} & \beta 4_{5 i} \\
\beta 5_{1 i} & \beta 5_{2 i} & \beta 5_{3 i} & \beta 5_{4 i} & \beta 5_{5 i}
\end{array}\right]\left[\begin{array}{c}
\Delta \ln G D P_{t-i} \\
\Delta \ln E B T_{t-i}^{N E W} V_{t-i} \\
\Delta I N I N S_{t-i} \\
\Delta I N F_{t-i}
\end{array}\right] \\
+\left[\begin{array}{c}
\theta \\
\vartheta \\
\psi \\
\omega \\
\delta
\end{array}\right]\left[\begin{array}{l}
E C T_{t-i} \\
E C T_{t-i} \\
E C T_{t-i} \\
E C T_{t-i} \\
E C T_{t-i}
\end{array}\right]+\left[\begin{array}{c}
\varepsilon_{1 t} \\
\varepsilon_{2 t} \\
\varepsilon_{3 t} \\
\varepsilon_{4 t} \\
\varepsilon_{5 t}
\end{array}\right]
\end{aligned}
$$

where $(1-L)$ represents the lag operator, $\mathrm{ECT}_{\mathrm{t}-1}$ is the lagged error-correction term derived from the long-run cointegrating relationship, $\varepsilon_{1 t}, \varepsilon_{2 t}, \varepsilon_{3 t}, \varepsilon_{4 t}$, and $\varepsilon_{5 t}$ are serially independent random errors with mean zero and finite covariance matrix, $p$ is the optimal lag length and the lag selection is based on the Schwarz Bayesian Criterion (SBC).

\section{Findings and Discussion}

In Table 2, the Augmented Dickey-Fuller (ADF) test shows that GREV, INVS and INF are stationary at level or $I(0)$, while other variables are stationary at first difference or $I(1)$. The ADF test results show that the variables used in this study have a mix of stationarities of $I(0)$ and /(1). Therefore, this study proceeds with an ARDL estimation for the cointegration test.

Table 1: Unit Root Test

\begin{tabular}{lcccc}
\hline \multirow{2}{*}{ Variable } & \multicolumn{3}{c}{ Augmented Dickey-Fuller } \\
\cline { 2 - 5 } & \multicolumn{3}{c}{ Level } & \multicolumn{2}{c}{ First Difference } \\
\cline { 2 - 5 } & Intercept & $\begin{array}{c}\text { Trend \& } \\
\text { Intercept }\end{array}$ & Intercept & $\begin{array}{c}\text { Trend \& } \\
\text { Intercept }\end{array}$ \\
\hline GDP & $-1.2890(0)$ & $-2.3028(0)$ & $-8.5449(0)^{* * *}$ & $-8.5384(0)^{* * *}$ \\
DEBT $^{\text {OLD }}$ & $-1.3542(0)$ & $-1.0924(0)$ & $-7.2791(0)^{* * *}$ & $-7.3078(0)^{* * *}$ \\
DEBT $^{\text {NEW }}$ & $-1.3670(0)$ & $-1.0770(0)$ & $-7.3744(0)^{* * *}$ & $-7.4207(0)^{* * *}$ \\
GREV & $-3.4313(4)^{* *}$ & $-3.4531(4)^{*}$ & $-5.0394(3)^{* * *}$ & $-5.0556(3)^{* * *}$ \\
INVS & $-2.7252(4)^{*}$ & $-4.0343(2)^{* *}$ & $-3.6251(3)^{* * *}$ & $-3.6081(3)^{* *}$ \\
INF & $-0.4164(0)$ & $-3.2685(1)^{*}$ & $-7.3310(0)^{* * *}$ & $-7.2899(0)^{* * *}$ \\
\hline
\end{tabular}

Note: Asterisks *,** and $* * *$ denote significance levels $10 \%, 5 \%$ and $1 \%$ respectively. The number in brackets ( ) indicates lag length; Automatic lag selection by Schwarz Bayesian Criterion (SBC) for ADF test.

The results of the ARDL bound test for cointegration are presented in Table 3. The null hypotheses of no cointegration are rejected for both equations (3) and (4). Thus, there exists a long-run relationship among the variables. Table 4 reports long-run coefficients for both equations. The results indicate a negative relationship between external debt and economic growth in Malaysia. A one percent increase in the old definition of external debt (DEBT ${ }^{\mathrm{OLD}}$ ) 
reduces economic growth by $0.58 \%$, which is lower than the effect of the new definition of external debt (DEBT ${ }^{\mathrm{NEW}}$ ) on economic growth. Other control variables in both equations (3) and (4), such as investment (INVS) and inflation (INF), are found to have a positive effect on Malaysia's economic growth. According to Munir, Mansur, and Furuoka (2009), a positive relationship between inflation and economic growth suggests that inflation may escalate economic growth in Malaysia when the threshold level is below 3.89\% (Dotsey and Sarte, 2000). On the other hand, the government revenue (GREV) had a negative effect on economic growth. As tax revenue contributes to a large portion of government revenue, tax rate increment may distort future economic growth (Poulson and Kaplan, 2008).

Table 2: ARDL Bound Test

\begin{tabular}{lcc}
\hline & Model (3) & Model (4) \\
\hline F-Statistics & $7.5731^{* * *}$ & $9.8935^{* * *}$ \\
Lag order & $(1,1,1,1,0)$ & $(1,1,0,0,0)$ \\
\hline Critical Value $(\mathrm{k}=4)$ & Lower Bound $\mathrm{l}(0)$ & Upper Bound I(1) \\
\hline $1 \%$ & 3.29 & 4.37 \\
$5 \%$ & 2.56 & 3.49 \\
$10 \%$ & 2.20 & 3.09 \\
\hline
\end{tabular}

Note: Asterisks $*, * *$ and $* * *$ denote significance levels $10 \%, 5 \%$ and $1 \%$ respectively. The model is selected based on the Schwarz Bayesian Criterion (SBC). The critical values are based on (Pesaran et al., 2001).

Table 4: ARDL Long-Run

Dependent Variable: GDP

\begin{tabular}{lllc}
\hline \multicolumn{3}{c}{ Model (3) } & \multicolumn{2}{c}{ Model (4) } \\
\hline Variables & Coefficient & Variables & Coefficient \\
\hline DEBT OLD & $-0.5755^{* * *}$ & DEBT & $-0.7281^{* * *}$ \\
GREV & $-0.4275^{* * *}$ & GREV & $-0.2067^{* *}$ \\
INVS & $0.2616^{*}$ & INVS & $0.4940^{* * *}$ \\
INF & $2.9556^{* * *}$ & INF & $3.5857^{* * *}$ \\
C & $-1.4907^{*}$ & C & $-3.4706^{* * *}$ \\
ECT & $-0.2695^{* * *}$ & ECT $_{\text {t-1 }}$ & $-0.2381^{* * *}$ \\
\hline \multicolumn{4}{c}{ Diagnostic Test } \\
\hline Serial Correlation, LM & 2.3031 & Serial Correlation, LM & 2.8090 \\
Heteroskedasticity, ARCH & 8.7098 & Heteroskedasticity, ARCH & 9.1631 \\
\hline
\end{tabular}

Note: Asterisks *,** and $* * *$ denote significance levels $10 \%, 5 \%$ and $1 \%$ respectively. The model is selected based on the Schwarz Bayesian Criterion (SBC).

Table 5 shows that there exists no direct causal relationship between external debt (old definition) and economic growth. However, the bilateral causal relationship between external debt and economic growth can be linked through government revenue and investment (DEBT ${ }^{\mathrm{OLD}} \rightarrow \mathrm{GREV} \rightarrow$ INVS $\rightarrow$ GDP; DEBT ${ }^{\mathrm{OLD}} \rightarrow \mathrm{INF} \rightarrow$ INVS $\rightarrow$ GDP; GDP $\rightarrow$ GREV $\rightarrow$ INVS $\rightarrow$ DEBT $^{\text {OLD }}$; GDP $\rightarrow$ INF $\rightarrow$ INVS $\rightarrow$ DEBT $^{\text {OLD }}$.

On the other hand, when the new definition of external debt is introduced, there is a direct and indirect reversed causal relationship running from gross domestic product to external debt (GDP $\rightarrow$ DEBT $^{\mathrm{NEW}}$ and GDP $\rightarrow$ INF $\rightarrow \mathrm{DEBT}^{\mathrm{NEW}}$ ). In addition, government revenue 
granger cause external debt operates through investment and gross domestic product (GREV $\rightarrow$ INVS $\rightarrow$ DEBT $^{\text {NEW; }}$ GREV $\rightarrow$ INVS $\rightarrow$ GDP $\rightarrow$ DEBT $^{\text {NEW}}$ ). These findings suggest that nonresidents' holding of local-currency debt securities is highly driven by economic performance.

Table 5: Granger Causality

\begin{tabular}{lcccccc}
\hline \multicolumn{7}{c}{ Previous Definition External Debt (Model 1) } \\
\cline { 2 - 6 } Dependent Variable & \multicolumn{7}{c}{ Independent Variable } & \multirow{2}{*}{ ECT $_{\mathrm{t}-1}$} \\
\cline { 2 - 6 } & $\Delta \mathrm{GDP}$ & $\Delta \mathrm{DEBT}$ & $\Delta \mathrm{GREV}$ & $\Delta \mathrm{INVS}$ & $\Delta \mathrm{INF}$ & \\
\hline \multirow{2}{*}{$\Delta \mathrm{GDP}$} & - & 0.0424 & 0.2341 & $7.5737^{* * *}$ & 2.1324 & -0.4715 \\
$\Delta$ DEBT & 2.4169 & - & 0.0285 & $3.2934^{*}$ & 2.0046 & -0.6615 \\
$\Delta$ GREV & $5.7042^{* *}$ & $7.8864^{* * *}$ & - & $3.3711^{*}$ & 1.1771 & $-2.0273^{*}$ \\
$\Delta \mathrm{INVS}$ & 0.9881 & 1.9312 & $17.6388^{* * *}$ & - & $3.0288^{*}$ & -0.1547 \\
$\Delta \mathrm{INF}$ & $6.2302^{* * *}$ & $8.3228^{* * *}$ & 0.9894 & 0.002 & - & -0.0522 \\
\hline
\end{tabular}

\section{Redefinition External Debt (Model 2)}

\begin{tabular}{lcccccc}
\hline \multirow{2}{*}{ Dependent Variable } & \multicolumn{7}{c}{ Independent Variable } & \multirow{2}{*}{ ECT $_{\mathrm{t}-1}$} \\
\cline { 2 - 6 } & $\Delta \mathrm{GDP}$ & $\Delta \mathrm{DEBT}$ NEW & $\Delta \mathrm{GREV}$ & $\Delta \mathrm{INVS}$ & $\Delta \mathrm{INF}$ & \\
\cline { 1 - 5 } & - & 0.4649 & 0.3445 & $4.2030^{* *}$ & 1.4736 & $-0.6935^{*}$ \\
$\Delta \mathrm{DEBT}^{\mathrm{NEW}}$ & $3.3885^{*}$ & - & 0.028 & $7.4092^{* * *}$ & $3.1988^{*}$ & -0.6815 \\
$\Delta \mathrm{GREV}$ & 1.4205 & 2.5628 & - & 1.2062 & 0.3237 & -0.717 \\
$\Delta \mathrm{INVS}$ & 1.7467 & 2.1702 & $18.7791^{* * *}$ & - & 2.2663 & 0.0954 \\
$\Delta \mathrm{INF}$ & $8.0917^{* * *}$ & $11.6179^{* * *}$ & 1.1698 & 0.7259 & - & -0.0427
\end{tabular}

Note: Asterisks *,** and $* * *$ denote significance levels $10 \%, 5 \%$ and $1 \%$ respectively. $\Delta$ is the first difference operator.

Figure 4: Summary of Short-Run Causal Linkages (Previous Definition of External Debt)

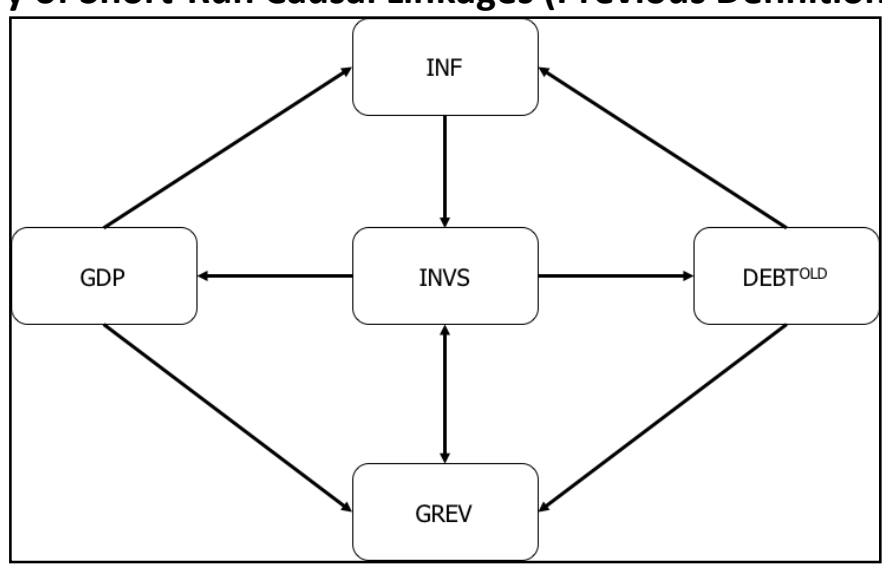


Figure 5: Summary of Short-Run Causal Linkages (Redefinition of External Debt)

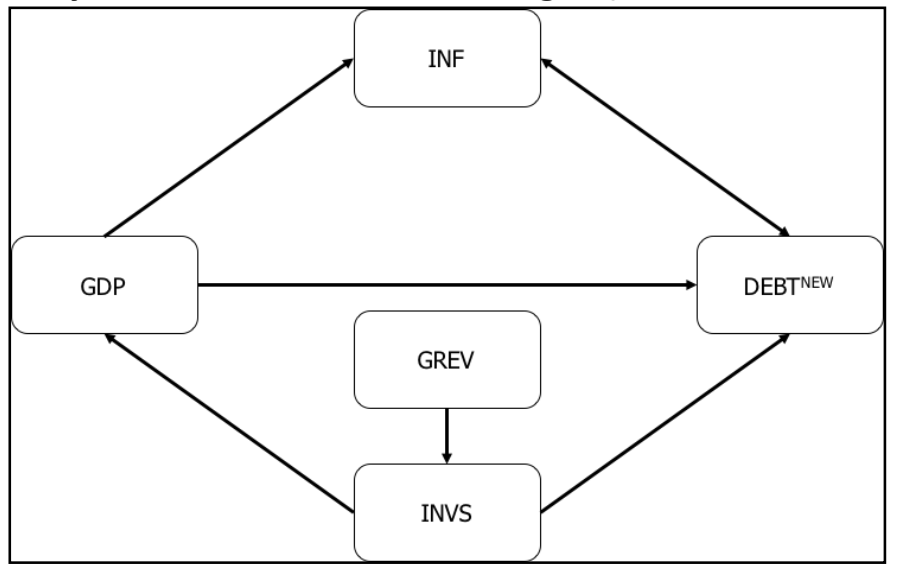

Although the cointegration test shows that there are cointegration relationships among the variables, it does not provide the dynamic interactions and strength of causal relations between these variables. Therefore, this study employed variance decomposition and impulse response analyses to examine the effect of external debt on economic growth.

Variance decomposition analyses in Table 6 report the estimates of the fluctuations in economic growth caused by a shock in external debt. It shows that the total shocks in the new definition of external debt account for about $40 \%$, a figure that is slightly higher than the total shocks in the old definition of external debt, in economic growth fluctuations. This implies that external debt is the most exogenous variable inherent in both models

Table 6. Variance Decomposition

\begin{tabular}{|c|c|c|c|c|c|}
\hline \multirow{2}{*}{$\begin{array}{l}\text { Horizon } \\
\text { (Quarters) }\end{array}$} & \multicolumn{5}{|c|}{ Forecast error variance attributed to the economic growth (Model 1) } \\
\hline & GDP & DEBT OLD & GREV & INVS & INF \\
\hline 1 & 25.3256 & 46.293 & 25.4555 & 0.4106 & 2.5155 \\
\hline 4 & 23.7711 & 39.2996 & 24.2246 & 6.3868 & 6.3179 \\
\hline 8 & 23.7525 & 39.2971 & 24.1887 & 6.4425 & 6.3192 \\
\hline 12 & 23.7523 & 39.2969 & 24.1881 & 6.4437 & 6.3191 \\
\hline 16 & 23.7523 & 39.2968 & 24.1881 & 6.4437 & 6.3191 \\
\hline 20 & 23.7523 & 39.2968 & 24.1881 & 6.4437 & 6.3191 \\
\hline 24 & 23.7523 & 39.2968 & 24.1881 & 6.4437 & 6.3191 \\
\hline
\end{tabular}

Horizon Forecast error variance attributed to the economic growth (Model 2)

\begin{tabular}{cccccc} 
(Quarters) & GDP & DEBT & GREV & INVS & INF \\
\hline 1 & 24.6622 & 52.8514 & 19.4007 & 0.0748 & 3.0108 \\
4 & 27.3729 & 43.3485 & 19.0297 & 3.513 & 6.736 \\
8 & 29.3437 & 41.8114 & 18.7175 & 3.4021 & 6.7254 \\
12 & 29.8743 & 41.4277 & 18.6078 & 3.3741 & 6.7162 \\
16 & 30.011 & 41.3293 & 18.579 & 3.3669 & 6.7138 \\
20 & 30.0464 & 41.3038 & 18.5715 & 3.3651 & 6.7132 \\
24 & 30.0556 & 41.2972 & 18.5696 & 3.3646 & 6.7131 \\
\hline
\end{tabular}


Figure 6: Impulse Response of Economic Growth to External Debt

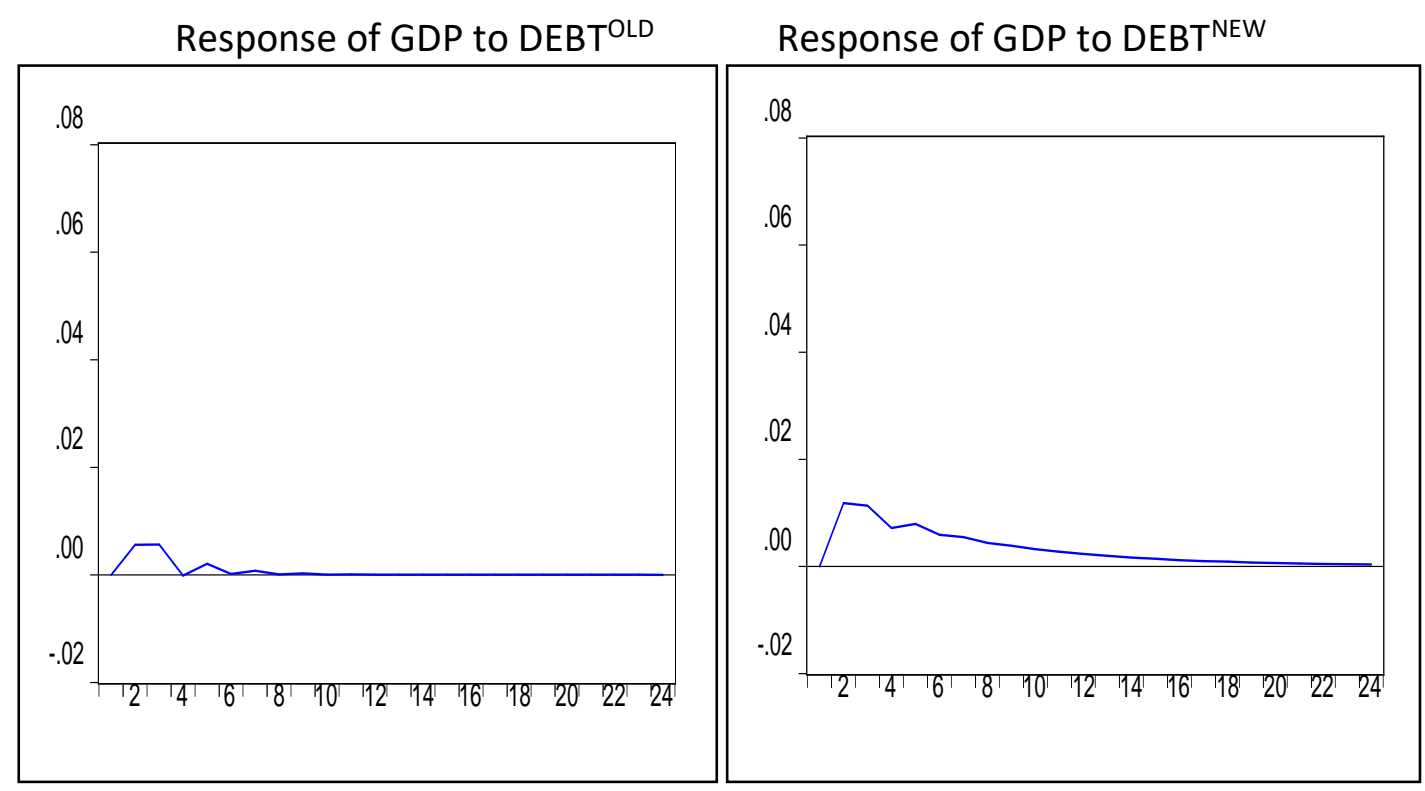

Note: Response to Cholesky One S.D. Innovations.

The estimates of the responses of economic growth to shocks in external debt are summarised in Figure 6. Economic growth responds positively to shocks in both definitions of external debt. However, the positive effect from the old definition of external debt dices out faster than the new definition. According to Daud et al. (2013), this indicates that there is an inverted U-shape relationship between accumulation external debt and economic growth in Malaysia. Therefore, economic growth responds negatively to external debt when the external debt has reached an optimal threshold level.

\section{Conclusion}

Previous studies were conducted to explore the linkage between external debt and economic growth, using various approaches and in different geographical regions. However, there seem to be a few studies relating to this topic that focused on a specific country level, and there is no study that takes into consideration the new definition of external debt. Hence, this study's primary aim is to address the gap in the literature by examining the effects of external debt on economic growth by allowing the external debt to be taken into consideration in terms of the non-residents' holding of domestic bonds.

Using time series econometric approaches and quarterly data of Malaysia from 1997 Q1 to 2016 Q4, this study demonstrated a positive effect of the previous defintion and redefinition of external debt on economic growth. The positive effect from the previous definition of external debt dices out more quickly than the new definition of external debt. In addition, the results of the Granger causality test reveal the existence of short-run bilateral causality relationships between external debt and economic growth. These findings could be explained by the fact that external borrowing was an important source for the government to finance all expenditures to stimulate economic development. However, the positive effect might fade in the long term if the external debt level reaches to a certain threshold point or when Malaysia suffers from capital outflows.

According to IMF, the uncertainty of external risk, where foreign investors hold large positions in Malaysia's debt securities will expose the country to further capital outflow 
(International Monetary Fund, 2016). This uncertainty could bring real economic loss. Therefore, to avoid the risk of being caught in a debt overhang situation, policymakers should play an effective role in monitoring Malaysia's external debt position and allocate the funds effectively. Malaysia's funds allocation focus have to ensure the socio-economic well-being of Malaysian, implement institutional reforms and foster an entrepreneurial economy in order to restore to the competitive country (Ernst \& Young, 2018). There is also the need for accountability in governance, good macroeconomic policy environment and the enhanced exportation of domestic products. As such, the ultimate goal of the economic policy should enable Malaysia to achieve a high level of economic growth by 2024 (OECD, 2019).

Future research may gather complete data of Malaysia's redefinition of external debt and expand the sample period to the present time. Moreover, it may access others country samples or larger samples that also adopt the new definition of external debt practices. This makes it possible for a more reliable picture on the role of the new definition of external debt on economic growth.

\section{Acknowledgement}

This work is part of the Malaysian Ministry of Education's Fundamental Research Grant Scheme (FRGS) (project number: FRG0458-2017).

\section{References}

Abdelhadi, S. A. (2013). External Debt and Economic Growth : Case of Jordan (1990-2011). Journal of Economics and Sustainable Development. 4(18):26-33.

Abdullah, A. S., Razali, N. M. (2017). Factors Affecting Foreign Investors' Bondholding in Malaysia. Quarterly Bullentin, Bank Negara Malaysia. (June), 33-40.

Ahmed, Q. M., Butt, M. S., Alam, S. (2000). Economic Growth, Export, and External Debt Causality: The Case of Asian Countries. Pakistan Development Review. 39(4 PART II), 591608.

Bakar, N. A. A., Hassan, S. (2008). Empirical Evaluation On External Debt of Malaysia. International Business \& Economics Research Journal. 7(2), 95-108.

Bank Negara Malaysia. (2014). Economic and Financial Development in Malaysia in the First Quarter of 2014. Ref. No.: 05/14/05. (May).

Bank Negara Malaysia. (2016). Annual Report. Kuala Lumpur: Bank Nagara Malaysia.

Choong, C., Lau, E., Liew, V. K., Puah, C. (2010). Does Debts Foster Economic Growth? The Experience of Malaysia. African Journal of Business Management. 4(8), 1564-1575.

Clements, B., Bhattacharya, R., Nguyen, T. Q. (2003). External Debt, Public Investment, and Growth in Low-Income Countries. IMF Working Papers No.03/249. Washington DC.: International Monetary Fund.

Cordella, T., Ricci, L. A., Ruiz-Arranz, M. (2010). Debt Overhang or Debt Irrelevance? IMF Staff Papers. 57(1), 1-24.

Daud, S. N. M., Ahmad, A. H., Azman-Saini, W. N. W. (2013). Does External Debt Contribute to Malaysia Economic Growth? Economic Research-Ekonomska Istraživanja. 26(2), 5168.

Dotsey, M., Sarte, P. D. (2000). Inflation uncertainty and growth in a cash-in-advance economy. Journal of Monetary Economics. 45(3), 631-655.

Elbadawi, I., Ndulu, B., \& Ndung'u, N. (1997). Debt Overhang and Economic Growth in SubSaharan Africa. External Finance for Low-Income Countries.

Ernst \& Young. (2018). Budget 2019: Malaysia. Ernst \& Young Tax Consultants Sdn. Bhd. 
$6(5)$.

Fosu, A. K. (1999). The External Debt Burden and Economic Growth in the 1980s: Evidence from sub-Saharan Africa. Canadian Journal of Development Studies/Revue Canadienne D'études Du Développement. 20(April 2015), 307-318.

Griffin, K. B., Enos, J. T. (1970). Foreign Assistance: Objectives and Consequences. Economic Development and Cultural Change. 18(3), 313-327.

International Monetary Fund. 2016. Staff Report for the 2016 Article IV Consultation. IMF Country Report No.16/110. Washington DC.: International Monetary Fund.

Jayaraman, T. K., Lau, E. (2009). Does external debt lead to economic growth in Pacific island countries. Journal of Policy Modeling. 31(2), 272-288.

Jilenga, M. T., Xu, H., Gondje-Dacka, I.-M. (2016). The Impact of External Debt and Foreign Direct Investment on Economic Growth: Empirical Evidence from Tanzania. International Journal of Financial Research. 7(2), 154-162.

Krugman, P. (1988). Financing VS. Forgiving a Debt Overhang. Journal of Development Economics. 29, 253-268.

Lau, E., Lee, A. S.-Y., Baharumshah, A. Z. (2015). External Debt and Economic Growth Nexus: Evidence From Malaysia, Thailand and Philippines. 16th International Academic Conference, Amsterdam. 292-304.

Munir, Q., Mansur, K., Furuoka, F. (2009). Inflation and Economic Growth in Malaysia - A Threshold Regression Approach. ASEAN Economic Bulletin. 26(2), 180.

OECD. (2019). OECD Economic Surveys: Malaysia 2019. OECD Publishing. (July). Retrieved from www.oecd.org/eco/surveys/economic-survey-malaysia.htm

Pattillo, C., Poirson, H., Ricci, L. (2002). External Debt and Growth. IMF Working Papers 02/69, 1-47.

Pesaran, M. H., Shin, Y., Smith, R. J. (2001). Bounds Testing Approaches to the Analysis of Level Relationships. Journal of Applied Econometrics. 16(3), 289-326.

Poulson, B. W., Kaplan, J. G. (2008). State Income Taxes and Economic Growth. Cato Journal. 28(1), 53-70.

Reinhart, C. M., Rogoff, K. S. (2010). Growth in a Time of Debt. American Economic Review: Paper \& Proceedings. 100, 573-578.

Roscoe, M., Duggar, E. H. (2016). The Evolution of Emerging Markets External Debt: Private Sector Debt Drives Broad-Based Build- Up of Emerging Markets External Vulnerability Risks. Moody's Investors Service Report.

Schclarek, A. (2004). Debt and Economic Growth in Developing and Industrial Countries. Lund University Working Paper No. 2005:34. Lund: Department of Economics, Lund University.

Schclarek, A., Ramon-Ballester, F. (2005). External Debt and Economic Growth in Latin America. mimeo. Lund: Department of Economics, Lund University.

Shabbir, S. (2013). Does External Debt Affect Economic Growth: Evidence from Developing Countries (63), 1-20.

Were, M. (2001). The Impact of External Debt on Economic Growth in Kenya An Empirical Assessment. UNU-WIDER Discussion Paper No. 2001/116. 